\title{
TYPOLOGY OF VILLAGE GOVERNANCE ASSESSED BASED ON SOCIOLOGICAL PERSPECTIVE
}

\author{
Suci Flambonita ${ }^{1}$
}

\begin{abstract}
Along with modern developments that exist today, various polemics have emerged in determining the typology of village governance that is in accordance with the principles of legal policy (legal policy) related to the sociological foundation in the form of understanding village conditions is absolutely necessary. Therefore, a stronger State institution is needed in dealing with the rational division of tasks and authorities between the State and regions (villages). In its preparation, it is necessary to describe a sociological condition of an intact village, which is viewed from the village elements which include the village area, village life system and village administration. The method and approach used was empirical (sociological research). There were several arguments for the need to understand the condition of the village sociologically where various villages throughout Indonesia have always been the basis of community livelihoods that have autonomy in managing the governance of the population, local institutions and economic resources with all the local wisdom possessed by local Indonesian communities. Furthermore, the regulation on village governance is intended to respond to the globalization process marked by the liberalization process of information, economy, technology, culture, etc.
\end{abstract}

Keywords: Typology, village administration, sociology

\section{The Introduction}

To determine the typology of village governance in accordance with the principles of legal policy, a sociological foundation in the form of an understanding of village conditions is absolutely necessary. There are several arguments about the need to understand the conditions of the village, among others. First, sociologically, various villages throughout Indonesia have always been the basis of community livelihoods which in fact have autonomy in managing power and governance over the population, local institutions and economic resources. The same applies to efforts aimed at creating a just and prosperous society, as mandated in the preamble to the 1945 Constitution. This must start with a development paradigm from below (village), considering that most Indonesians with all their problems in the village. Village communities tend to be passive in carrying out social and economic changes that are different from development which tends to be growthoriented and city-biased (Uu et al., 2014) causes high urbanization of rural residents to cities and poverty and many cases of underdevelopment in villages. Second, all Indonesian local communities have strong local wisdom that contains a "spirit" of sufficiency, balance and sustainability in managing natural resources and people. Therefore, the idea of future village governance arrangements is intended to repair the village's social, cultural, economic and political damage. Village autonomy should be able to restore the livelihood

1 Fakultas Hukum Universitas Sriwijaya, Palembang, Indonesia, Email: suciflambonita@fh.unsri.ac.id 
base of village communities and strengthen the village as a place for strong and independent community communities.

Third, regulations regarding village governance are intended to respond to the globalization process marked by the liberalization process of information, economy, technology, culture, etc. This challenge is needed by State institutions to be stronger in dealing with the rational division of tasks and authorities between the state and regions (villages). The basic principle that must be adhered to in the division of tasks and authorities is that regions and villages must be placed as flexible compartments within the state, namely by realizing a public welfare and more fundamentally the survival ability of the State. This is why regional or village autonomy is likely to weaken the NKRI development or survival ability. To see this, a sociological depiction of the condition of an intact village is needed which can be viewed from village elements, including village areas, village life arrangements and village governance (Agusta, 2014). Indonesia has around 73,000 (seventy three thousand) villages. These villages are divided into ordinary villages and traditional villages. This causes two concepts of society to differentiate between one another, namely (i) Village communities, and (ii) Indigenous communities(Uu et al., 2014)

\section{Research methods}

The research method used is socio legal research through a cluster approach and identification. This research was an Empirical Juridical Research (Field Research). The aim of this research was to explain in detail about the typology of village governance assessed based on sociological perspective. Furthermore, the primary data analysis obtained was carried out using the statute approach which was used by using legislation and regulations especiallyvarious polemics have emerged in determining the typology of village governance that is in accordance with the principles of legal policy related to the sociological foundation in the form of understanding village conditions is absolutely necessary. Therefore, a stronger State institution is needed in dealing with the rational division of tasks and authorities between the State and regions (villages). In its preparation, it is necessary to describe a sociological condition of an intact village. The sociological-juridical / social law culture is also needed in analyzing the the typology of village governance assessed based on sociological perspective. Proportionally, it was used to study a legal processes, in term of the legal is viewed from the reality, because social facts can be explained with legal assistance and legal principles that can be explained with the help of social facts with the study of village elements which include the village area, village life system and village administration.

\section{Discussion and Results \\ Definitions of Village According to Experts}

According to R. Bintarto, the village is "an embodiment caused by the physiographic, socio-economic, political and cultural elements present there in the reciprocal relationship and influence with other regions" . PJ. Bournen defined village as "One of the ancient forms of coexistence as many as several thousand people almost all of whom know each other; most of which include living from agriculture, fisheries and other businesses which can be 
influenced by the laws and will of nature. Besides, there are many close family ties, obedience and social rules in that residence ." Furthermore, according to I nyoman Beratha, the village or with its original name which is the same level as a legal community unit based on the original structure is a" legal entity "and is also a A "government agency" which is part of a subdistrict or area that covers it. In connection with this, RH. Unang Soenardjo stated that the village is a community unit based on custom and customary law that resides in an area with certain boundaries; have very strong physical and mental ties, both because of descent and because they share political, economic, social and security interests; have a jointly elected committee; has a certain amount of wealth and has the right to carry out his own household affairs.

Based on the definitions of village according to these experts, it can be concluded that a village is an area inhabited by a number of residents who know each other on the basis of kinship and / or political, social, economic and security interests, which in its growth become a legal community unit based on custom so as to grow. physical and mental ties between each of its citizens where the citizens generally live from the agricultural sector, have the right to manage their own households and are administratively under the district / city government. As a manifestation of democracy, a Village Consultative Body or other designation is formed in accordance with the culture that develops in the Village concerned in the implementation of Village government where it functions as an institution that regulates the administration of Village governance. Village status is a government unit under the district / city. A village is different from a sub-district whose status is below the camat. The village is a legal community unit that has territorial boundaries that are authorized to regulate and manage the interests of the local community based on local origins and customs and cultural diversity (Iskandar et al., 2015)which are recognized and respected in the government system of the unitary state of the Republic of Indonesia. (Law No. 32 of 2004) as stipulated in Law Number 5 of 1979 concerning Village Government, the lowest unit of government under the sub-district is called the village nomenclature(Yuningsih \& Subekti, 2016). In connection with this, one of the items regarding the form or status of a village which is in fact a village unit is the status of a village which is a government unit under a district / city. Meanwhile, the kelurahan is only the work area of the lurah under the camat which does not have the right to regulate and manage the interests of the local community. This is intended to create an efficient village government so that the village can accept development tasks that were the priority of the government at that time. Based on these provisions, all the lowest government units such as nagari in West Sumatra, Gampong in Aceh, Marga in South Sumatra, forest in North Sumatra, Kampung in Kalimantan and others, change their nomenclature to become villages. (Security, 2013)

\section{Village in terms of origin and type of village historical growth}

Based on the history of village growth, there are at least four types of villages in Indonesia, namely as follows:(Benda-Beckmann \& Turner, 2018)

1. Traditional Village (self-governing community). Traditional village is a form of original village and the oldest in Indonesia. The concept of "original autonomy" refers to the meaning of customary villages. 
Traditional village basically regulates and manages its own wealth without state interference. Customary villages do not carry out administrative tasks given by the state. One example of a traditional village is Pakraman village in Bali.

2. Administrative Village (local state government) is a village which is an administrative service unit of the central government. Administrative villages are formed by the state and are an extension of the state's arm to carry out administrative tasks given by the state. Administrative villages lack substantially autonomy and democracy.

3. Autonomous village as a local self-government. Autonomous villages are villages that are formed based on the principle of decentralization by law. The autonomous village has clear authority because it is regulated in the law of its formation. Therefore, the autonomous village has full authority to regulate and manage its own household affairs. Autonomous villages receive a clear delegation of authority from the central government, have the right to form their own government institutions, have village policy-making bodies, have the authority to make village regulations and also receive financial decentralization from the state.

4. Mixed Village (customary and semi-autonomous), namely the type of village that has a mixture of authority between original autonomy and semi-formal autonomy. What is meant by mixed here means that the original autonomy of the village is recognized by law whereby the village is also given the transfer of authority from the district / city. It is called semi-autonomous because the model of handover of government affairs from autonomous regions to government units under it is not known in the decentralization theory, because according to the theory of decentralization or autonomy, the handover of government affairs only comes from the central government.

In legal politics, village government is in principle determined based on 3 (three) perspectives, namely: Sociological Perspective, Philosophical Perspective and Sociological Perspective. This paper will only discuss typology and village profiles from a sociological perspective without reducing the meaning from other perspectives.

\section{Typology of villages in Indonesia from a sociological perspective}

\section{Village condition from the Regional perspective}

Empirically, villages in various parts of Indonesia show diversity. Regional differences bring consequences to differences in society, life and even differences in governance. Meanwhile, with regard to regional elements, there are at least three categories of village areas in Indonesia, namely a) Villages that occupy the highlands or mountains $b$ ) villages located in coastal areas or banks of large rivers and c) villages located in the area between the mountains and the coast or land. The elements of the village area can be divided into three sub-regions, namely a) quantity area b) regional quality and c) area distance that affects economic conditions and the development of a village. Furthermore, based on the quantity or area sub-region, the village area is divided into a) a village whose territory is very wide b) villages whose 
territory is medium and c) a village whose territory is less extensive. In terms of regional quality (soil fertility level), villages can be divided into a) villages with very high soil fertility b) villages with moderate soil fertility, and c) villages with relatively low or poor soil fertility. The level of soil fertility in the village area will be related to the livelihoods or economy of the population. For this reason, there will be three categories of livelihood for the villagers, namely as follows: a) villages whose economy rests on agricultural clumps, including plantations b) villages whose economic production lies in fishery clumps and c) villages whose economies depend on the trade in goods or services sector (Lastini et al., 2011).

\section{Table 1}

\section{Economic Typology in Village Areas}

\begin{tabular}{|l|l|l|}
\hline \multicolumn{3}{|c|}{ Village Economy Category } \\
\hline $\begin{array}{l}\text { Dominant in the form of } \\
\text { agricultural and plantation areas }\end{array}$ & $\begin{array}{l}\text { Dominant in the form } \\
\text { of fishing areas and } \\
\text { the like }\end{array}$ & $\begin{array}{l}\text { Dominant in the form } \\
\text { of trade in goods and } \\
\text { services }\end{array}$ \\
\hline $\begin{array}{l}\text { Rice fields, gardens, crops, } \\
\text { inland fisheries etc. }\end{array}$ & $\begin{array}{l}\text { Fishermen, fish } \\
\text { farming, ponds, } \\
\text { seaweed, etc. }\end{array}$ & $\begin{array}{l}\text { Food, beverage, } \\
\text { clothing services, } \\
\text { crafts, etc. }\end{array}$ \\
\hline
\end{tabular}

Source: Final Report of the Village Autonomy Revitalization Study

Next, based on area distance, village is divided into a. villages that are very far or remote from the center of the crowd. The main thing in creating a typology is to classify objects (cases) into groups whose members are similar to one another, but have clear differences with objects in other clusters(Security, 2013). Even facilities in the form of roads to access urban areas may not have been made yet, and $b$. villages that are relatively close to the center of the crowd which allows access to information and various developments in the city.

Table 2

Typology of distance to village area

\begin{tabular}{|l|l|l|}
\hline \multicolumn{3}{|c|}{ Village Territorial Distance Category } \\
\hline $\begin{array}{l}\text { The position of the area close to } \\
\text { the center of the crowd }\end{array}$ & $\begin{array}{l}\text { The position of the } \\
\text { area in the middle of } \\
\text { the crowd }\end{array}$ & $\begin{array}{l}\text { Position of the area } \\
\text { away from the center of } \\
\text { the crowd }\end{array}$ \\
\hline $\begin{array}{l}\text { It opens relatively quickly and } \\
\text { grows faster }\end{array}$ & $\begin{array}{l}\text { Relatively can open up } \\
\text { and develop at a } \\
\text { moderate pace }\end{array}$ & $\begin{array}{l}\text { Relatively closed and } \\
\text { has slow development }\end{array}$ \\
\hline
\end{tabular}

Source: Final Report of the Village Autonomy Revitalization Study

\section{Village condition from the perspective of the village community}

The village community is a group of individuals who have an agreement to live together in an area permanently, which is the main element of the village's existence. Based on the background of the population, the village community can be grouped into: a) village communities formed on the same social history, namely homogeneous village communities, where they have a strong kinship system, b) village communities whose community 
members come from different social backgrounds, so that they include heterogeneous village communities, as seen in the transmigration village, c) mixed village community, namely a mix of homogeneous village communities and heterogeneous newcomers to form a new and unique village community. Furthermore, based on quantity or population, the villages can be divided into a) densely populated villages b) village with moderate population, c) less densely populated villages. When viewed in terms of population quality, villages can be divided into a) typology of highly productive population, b) productive villagers and c) less productive villagers.

Table 3

Typology of Village Population Elements

\begin{tabular}{|l|l|l|}
\hline \multicolumn{3}{|c|}{ Village Population Element Category } \\
\hline Homogeneous villagers & & Mixed villagers \\
\hline Dense villagers & $\begin{array}{l}\text { Heterogeneous } \\
\text { villagers }\end{array}$ & Sparse villagers \\
\hline High productivity villagers & Medium villagers & $\begin{array}{l}\text { Low productivity } \\
\text { villagers }\end{array}$ \\
\hline
\end{tabular}

Source: Final Report of the Village Autonomy Revitalization Study

\section{Village Conditions from the Perspective of Village Life Management}

Village life system is a supra structure that covers the socio-cultural system of the village community that can survive and form a village identity. Village communities have two main environments, namely the physical environment that is within the territory and the non-physical environment or the socio-cultural environment. The two environments then form a collective knowledge system of the village community about themselves and their environment. Based on the conditions above, the village is based on social and cultural resilience. Meanwhile, based on the social resilience sub, village communities can be grouped into three parts, namely a) village communities who are socially more open so that it is shown by a dynamic attitude; b) more closed-off villagers where this is expressed statically; and c) village communities who are socially closed sometimes and sometimes open / conditional. Meanwhile, from sub-culture, villages can be divided into three parts, namely: a) the governance of village cultural life which is thick with cultural customs as its cultural identity, b) the governance of village cultural life whose local cultural customs are slightly faded, so that they replace it with a new culture as its identity, and c) traditional village cultural life, that is, some have been separated from cultural customs and some are still related to local culture.

Based on the two sub-elements of village life, namely the sub-elements of village social order and the sub-elements of village culture, these are translated into table 4 below:Lastini et al., 2011) 


\section{Table 4 \\ Typology of Village Population Elements}

\begin{tabular}{|l|l|l|}
\hline \multicolumn{3}{|c|}{ Village Life Management Category } \\
\hline $\begin{array}{l}\text { Sub elements of village social } \\
\text { order that are open and } \\
\text { dynamic }\end{array}$ & $\begin{array}{l}\text { Sub-elements of closed } \\
\text { and static village social } \\
\text { order }\end{array}$ & $\begin{array}{l}\text { Sub-elements of } \\
\text { conditional village } \\
\text { social order (between } \\
\text { static and dynamic) }\end{array}$ \\
\hline $\begin{array}{l}\text { The village culture is tenuous } \\
\text { with local customs }\end{array}$ & $\begin{array}{l}\text { Village cultural } \\
\text { arrangements that are } \\
\text { closely related to local } \\
\text { customs }\end{array}$ & $\begin{array}{l}\text { Transitional village } \\
\text { cultural arrangements } \\
\text { outry of customs from } \\
\text { customs) into local }\end{array}$ \\
\hline
\end{tabular}

Source: Final Report of the Village Autonomy Revitalization Study

\section{Village Conditions in the terms of Village Government Perspective}

Government is the apparatus that administers the government, while governance is an activity organized by the state apparatus (government). Village government consists of the village government and the Village Consultative Body (BPD), village heads and village officials (Articles 11 and 12 of Government Regulation Number 72 of 2005). In Javanese, they are called "parentahdesa", "perabotdesa", "bahu desa". The form of village government can be divided into a) form of formal village government, b) form of informal village government, and c) non-formal forms of government. Categorization can be carried out from the perspective of village leadership, where village leadership can be divided into: a) charismatic village leadership, b) administrative village leadership, and c) mixed village leadership. Materials can be categorized administratively into three parts: a) traditional village administration administrative system, b) modern village government administration system, and c). mixed village governance

Table 5

Elements Typology of the Villagers

\begin{tabular}{|l|l|l|}
\hline \multicolumn{2}{|c|}{ Village Life System Categorization } \\
\hline $\begin{array}{l}\text { Formal form of village } \\
\text { government }\end{array}$ & $\begin{array}{l}\text { Forms of informal } \\
\text { village government }\end{array}$ & $\begin{array}{l}\text { Mixed type of village } \\
\text { governance, between formal } \\
\text { and informal }\end{array}$ \\
\hline $\begin{array}{l}\text { Charismatic type of } \\
\text { village leadership }\end{array}$ & $\begin{array}{l}\text { Administrative type of } \\
\text { village leadership }\end{array}$ & $\begin{array}{l}\text { Mixed type of village } \\
\text { goverannce, between } \\
\text { charismatic and } \\
\text { administrative }\end{array}$ \\
\hline $\begin{array}{l}\text { Traditional village } \\
\text { administration }\end{array}$ & $\begin{array}{l}\text { Modern village } \\
\text { administrative system }\end{array}$ & $\begin{array}{l}\text { Mixed village administrative } \\
\text { governance, between } \\
\text { traditional and modern }\end{array}$ \\
\hline
\end{tabular}

Based on the overall village elements which consist of village territorial elements, village community elements, elements of village life and village administration along with their categories, they can be recapitulated and examined in the following table: 
Table 6

Recapitulation of Dimensional Typology of Villages in Indonesia

\begin{tabular}{|c|c|c|c|}
\hline \multicolumn{4}{|c|}{ Recapitulation of Village Typology in Indonesia } \\
\hline \multicolumn{4}{|c|}{ Village Territorial Elements } \\
\hline \multirow[t]{3}{*}{$\begin{array}{l}\text { Sub-Element of Village } \\
\text { Area Layout }\end{array}$} & $\begin{array}{l}\text { Has a location in } \\
\text { the mountainous } \\
\text { region }\end{array}$ & $\begin{array}{l}\text { It has a location } \\
\text { on the beach area }\end{array}$ & $\begin{array}{l}\text { Has a location } \\
\text { that is in a flat } \\
\text { area }\end{array}$ \\
\hline & $\begin{array}{l}\text { In terms of } \\
\text { quantity, the area } \\
\text { is very wide }\end{array}$ & $\begin{array}{l}\text { In terms of } \\
\text { quantity, the area } \\
\text { is quite wide }\end{array}$ & $\begin{array}{l}\text { In terms of } \\
\text { quantity, the } \\
\text { area is less } \\
\text { extensive }\end{array}$ \\
\hline & $\begin{array}{l}\text { The land is very } \\
\text { fertile }\end{array}$ & $\begin{array}{l}\text { The land is quite } \\
\text { fertile }\end{array}$ & $\begin{array}{l}\text { The land is less } \\
\text { fertile }\end{array}$ \\
\hline \multirow[t]{2}{*}{$\begin{array}{l}\text { Sub-element of village } \\
\text { resources }\end{array}$} & $\begin{array}{l}\text { The dominant } \\
\text { trade, goods and } \\
\text { services area }\end{array}$ & $\begin{array}{l}\text { A mix of regional } \\
\text { resources of } \\
\text { agriculture and } \\
\text { trade }\end{array}$ & $\begin{array}{l}\text { The dominant } \\
\text { agricultural and } \\
\text { plantation areas, } \\
\text { fisheries, etc. }\end{array}$ \\
\hline & $\begin{array}{l}\text { Food, drink, } \\
\text { services, clothing, } \\
\text { crafts, etc. }\end{array}$ & $\begin{array}{l}\text { A mixture of } \\
\text { agriculture and } \\
\text { cultivation with } \\
\text { trade }\end{array}$ & $\begin{array}{l}\text { Rice fields, } \\
\text { gardens, crops, } \\
\text { inland fisheries, } \\
\text { etc. }\end{array}$ \\
\hline \multirow[t]{2}{*}{$\begin{array}{l}\text { Sub-element of Village } \\
\text { area distance }\end{array}$} & $\begin{array}{l}\text { The position of } \\
\text { the area close to } \\
\text { the center of the } \\
\text { crowd }\end{array}$ & $\begin{array}{l}\text { Middle area } \\
\text { position with the } \\
\text { center of the } \\
\text { crowd }\end{array}$ & $\begin{array}{l}\text { Position of the } \\
\text { area away from } \\
\text { the center of the } \\
\text { crowd }\end{array}$ \\
\hline & $\begin{array}{l}\text { Relatively more } \\
\text { open and fast } \\
\text { growing }\end{array}$ & $\begin{array}{l}\text { Relatively open- } \\
\text { biased and } \\
\text { developing at a } \\
\text { moderate pace } \\
\end{array}$ & $\begin{array}{l}\text { Relatively closed } \\
\text { in its } \\
\text { development }\end{array}$ \\
\hline \multicolumn{4}{|c|}{ Village Community Elements } \\
\hline $\begin{array}{l}\text { Sub-elements of the } \\
\text { background and } \\
\text { character of the } \\
\text { villagers }\end{array}$ & $\begin{array}{l}\text { Heterogeneous } \\
\text { villagers }\end{array}$ & $\begin{array}{l}\text { Homogeneous } \\
\text { villagers }\end{array}$ & Mixed villagers \\
\hline $\begin{array}{l}\text { Sub element of village } \\
\text { population density }\end{array}$ & Dense villagers & Medium villagers & Sparse villagers \\
\hline $\begin{array}{l}\text { Sub-element of the } \\
\text { quality of the villagers }\end{array}$ & $\begin{array}{l}\text { High productivity } \\
\text { villagers }\end{array}$ & $\begin{array}{l}\text { Medium } \\
\text { productivity } \\
\text { villagers }\end{array}$ & $\begin{array}{l}\text { Low productivity } \\
\text { villagers }\end{array}$ \\
\hline \multicolumn{4}{|c|}{ Village Life System Elements } \\
\hline $\begin{array}{l}\text { Sub elements of village } \\
\text { social order }\end{array}$ & $\begin{array}{l}\text { An open and } \\
\text { dynamic social } \\
\text { order of the } \\
\text { village }\end{array}$ & $\begin{array}{l}\text { Village social } \\
\text { order which is } \\
\text { conditional to } \\
\text { static or dynamic }\end{array}$ & $\begin{array}{l}\text { Closed and static } \\
\text { village social } \\
\text { order }\end{array}$ \\
\hline $\begin{array}{l}\text { Sub elements of village } \\
\text { cultural order }\end{array}$ & $\begin{array}{l}\text { The village } \\
\text { culture is tenuous } \\
\text { with local } \\
\text { customs }\end{array}$ & $\begin{array}{l}\text { A transitional } \\
\text { village cultural } \\
\text { arrangement by } \\
\text { including local } \\
\text { customs and } \\
\text { customs from } \\
\text { outside }\end{array}$ & $\begin{array}{l}\text { Village cultural } \\
\text { arrangements } \\
\text { that are closely } \\
\text { related to local } \\
\text { customs }\end{array}$ \\
\hline
\end{tabular}




\begin{tabular}{|l|l|l|l|}
\hline \multicolumn{3}{|c|}{ Village Government Elements } \\
\hline $\begin{array}{l}\text { Sub elements of village } \\
\text { government forms }\end{array}$ & $\begin{array}{l}\text { Formal form of } \\
\text { village } \\
\text { government }\end{array}$ & $\begin{array}{l}\text { Mixed form of } \\
\text { government } \\
\text { between formal } \\
\text { and informal }\end{array}$ & $\begin{array}{l}\text { Informal forms } \\
\text { of government }\end{array}$ \\
\hline $\begin{array}{l}\text { Sub-elements of village } \\
\text { government leadership }\end{array}$ & $\begin{array}{l}\text { Formal village } \\
\text { leadership of } \\
\text { election results }\end{array}$ & $\begin{array}{l}\text { Mixed village } \\
\text { leadership } \\
\text { between modern } \\
\text { and charismatic }\end{array}$ & $\begin{array}{l}\text { Charismatic } \\
\text { village } \\
\text { leadership } \\
\text { without elections }\end{array}$ \\
\hline $\begin{array}{l}\text { Sub-elements of village } \\
\text { government } \\
\text { administration }\end{array}$ & $\begin{array}{l}\text { Modern village } \\
\text { government } \\
\text { administration }\end{array}$ & $\begin{array}{l}\text { The } \\
\text { administrative } \\
\text { governance of the } \\
\text { village is a } \\
\text { mixture of } \\
\text { modern and } \\
\text { traditional }\end{array}$ & $\begin{array}{l}\text { Traditional } \\
\text { village } \\
\text { governance }\end{array}$ \\
\hline
\end{tabular}

Source: Final Report of the Village Autonomy Revitalization Study

The village sub-element is basically a village unit. For this reason, each village sub-element that has the same character can be categorized in a village typology. Based on the analysis of the village sub-elements, there are 3 (three) categories of characteristics of villages in Indonesia in terms of the similarity of regional, social, life-order and village government elements into three village typologies, namely: Territorial village typology, Geneological village typology, and Mixed village typology.

Broadly speaking, the typology of territorial villages can be distinguished based on regional elements which are generally located in strategic plains, beaches or mountains. Village areas are measured and usually not very large. In general, the quality of village soil is very fertile or at least contains a lot of natural resources, both in agriculture and plantations with wet rice farming systems or plantations and cultivation. In addition, this village is supported by the position of the area that is relatively close to the center of the crowd so that access to information and mobility of the population is more dynamic and makes the village area open and develop more rapidly. In terms of elements of society or its inhabitants, territorial villages are more heterogeneous. At least some ethnic groups can live together with local residents. If observed from the village life system, this village community is more open and has a dynamic life so that the village cultural system no longer relies on the local village culture, even cultural acculturation has begun, either directly or indirectly. Furthermore, when viewed from the village administration, the territorial village has shown a more formal characteristic or form of village government. Leadership succession is carried out more openly with a direct election pattern which therefore makes village governance more modern.

Observed from the location of the region, geneological villages are generally located in mountainous areas or remote island coasts. The area tends to be very large and even unmeasurable. The level of soil fertility and the position of the village area which is remote and far from the crowd make the village relatively closed and difficult to reach so that its development is relatively slow. Judging from the population, the geneological village has a homogeneous population and still has kinship between the villagers. In 
connection with the order of their life patterns, villages with this category appear socially closed and static. From the elements of governance, the geneological village is more informal because basically the leadership element is more collective by customary stakeholders. Village head elections are usually only a formality. Its governance follows local customs which is known as traditional government.

A mixed village is a village that is developing, from sub-system agriculture to agriculture that leads to home industries. The products produced by the mixed village are sourced from agriculture, plantations, fisheries and local product trade services. Judging from the life order of the community, especially the social order, mixed villages are unique, sometimes dynamic and sometimes static so it is more accurately described as conditional. Likewise with cultural systems, mixed villages are more towards traditional modern. Mixed villages are the most common type of village in Indonesia. On the one hand, the culture in mixed villages seems to be advanced, but on the other hand, it is still tied to traditionalism or local customary culture (local culture).

\section{Conclusion}

A sociological basis in the form of understanding village conditions is absolutely necessary to determine the typology of village governance in accordance with the principles of legal policy. This aims to review the condition of a village based on various village typologies. There are several arguments for the need to understand the condition of the village. The first is related to the sociology of the village. The second,is related to the fact that all local Indonesian communities have strong local wisdom which contains a "spirit" of sufficiency, balance and sustainability in managing natural resources and people. Therefore, the idea of future village governance arrangements is intended to repair the village's social, cultural, economic and political damage. The third is related to regulations regarding village government. However, regional or village autonomy in this case will weaken the NKRI development or survival ability. Thus, a sociological depiction of the condition of a complete village is needed where implementation can be carried out by observing the village elements which include the village area, village life system and village administration.

\section{References}

Agusta, I. (2014). Transformasi Desa Indonesia 2003-2025. Kajian Perhimpunan Ekonomi Pertanian Indonesia (PERHEPI), 1-27. http://www.perhepi.org/wp-content/uploads/2014/11/TransformasiDesa-Indonesia-2003-2025_Dr.-Ivanovich-Agusta.pdf

Benda-Beckmann, K. von, \& Turner, B. (2018). Legal pluralism, social theory, and the state. Journal of Legal Pluralism and Unofficial Law, 50(3), 255-274. https://doi.org/10.1080/07329113.2018.1532674

Iskandar, S., Mahmud, A., \& Muslim, M. (2015). KARAKTERISTIK DAN AKAR MASALAH KEMISKINAN Kasus Pada 4 Tipologi Desa di Kabupaten Sumbawa. Jurnal Ekonomi Pembangunan: Kajian Masalah Ekonomi Dan Pembangunan, 11(1), 122. https://doi.org/10.23917/jep.v11i1.338

Lastini, T., Suhendang, E., \& Jaya, I. N. S. (2011). Village Typologies 
Analysis Based on Characteristic Variables of Private Forest. Jurnal Penelitian Hutan Tanaman, 155-168.

Security, F. (2013). ( TYPOLOGY OF THE VILLAGE IN KOTA BATU BASED ON. XIII(2).

Uu, P., Tahun, N. O., Desa, T., \& Mulyono, S. P. (2014). Sinergitas Penyelenggaraan Pemerintahan Desa Pasca Pemberlakuan Uu No. 6 Tahun 2014 Tentang Desa. Masalah-Masalah Hukum, 43(3), 438-444. https://doi.org/10.14710/mmh.43.3.2014.438-444

Yuningsih, N. Y., \& Subekti, V. S. (2016). Demokrasi dalam Pemilihan Kepala Desa? Studi Kasus Desa Dengan Tipologi Tradisional, Transisional, dan Modern di Provinsi Jawa Barat Tahun 2008-2013. Jurnal Politik, 1(2). https://doi.org/10.7454/jp.v1i2.21 


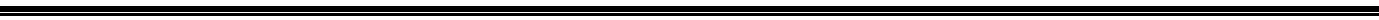

